NBER WORKING PAPER SERIES

\title{
DIGGING THE DIRT AT PUBLIC EXPENSE: GOVERNANCE IN THE BUILDING OF THE ERIE CANAL AND OTHER PUBLIC WORKS
}

\author{
Stanley L. Engerman \\ Kenneth L. Sokoloff \\ Working Paper 10965 \\ http://www.nber.org/papers/w10965 \\ NATIONAL BUREAU OF ECONOMIC RESEARCH \\ 1050 Massachusetts Avenue \\ Cambridge, MA 02138 \\ December 2004
}

The authors gratefully acknowledge valuable comments from David Dollar, Ed Glaeser, Claudia Goldin, Stephen Haber, Karla Hoff, Daniel Kaufmann, Zorina Khan, Naomi Lamoreaux, and participants in the NBER Conference on Corruption and Reform, held in Salem, MA, July 30-31, 2004. The views expressed herein are those of the author(s) and do not necessarily reflect the views of the National Bureau of Economic Research.

(C) 2004 by Stanley L. Engerman and Kenneth L. Sokoloff. All rights reserved. Short sections of text, not to exceed two paragraphs, may be quoted without explicit permission provided that full credit, including () notice, is given to the source. 
Digging the Dirt at Public Expense: Governance in the Building of the Erie Canal and Other Public Works

Stanley L. Engerman and Kenneth L. Sokoloff

NBER Working Paper No. 10965

December 2004

JEL No. N10, H4, O1, O2

\begin{abstract}
The Erie Canal was a mammoth public works project undertaken largely because the scope of the investment was beyond what a private firm could manage during the early 19th century. As with most public works, there were ample opportunities for public officials to realize private gains from the effort, and many did. On the whole, however, the construction of the Erie Canal (and most other major public works projects of the era) appears to have been well conceived and executed; it not only paid off more than its costs through tolls, but also generated substantial welfare improvements for the residents of the state of New York in the form of producer and consumer surplus and a wide range of positive externalities. Although there was obviously some fraud and mismanagement, the public authorities carried out the work at costs relatively close to those projected at the point of authorization. In an effort to try to place this episode in a broader perspective, we compare the ratio of actual expenditures on construction relative to the estimated costs at the time of authorization for the Erie Canal, to those for a range of other public works over American history up to the present day. It is our contention that this measure, albeit quite narrow in focus, is informative about the quality of governance of public resources. We highlight how, by this standard, the governance of public resources during the canal era stands up well in comparison with what we have seen since. Indeed, the cost overrun ratios have risen sharply over the last half-century, coinciding with both a marked increase in the relative size of the government sector as well as sustained economic growth. These patterns suggest how important it is that better measures and other means of systematically studying how the prevalence and effects of corruption vary across different contexts be developed.

Stanley L. Engerman Department of Economics University of Rochester

Rochester, NY 14627

and NBER

enge@ troi.cc.rochester.edu

Kenneth L. Sokoloff

Department of Economics

UCLA

Los Angeles, CA 90095-1477

and NBER

sokoloff@ucla.edu
\end{abstract}


It is generally accepted that no human society, at least since the early days of the Garden of Eden, has been free of corruption. Although conceptions of what range of behaviors is encompassed by the term vary widely, there is a grand tradition of laying responsibility for many social ills on it. One such social ill is the lack of economic growth, and economists have in recent years sought to elucidate mechanisms through which various forms of corruption might bring about inefficient actions, preventing a society from fully realizing its productive potential, at a point in time or over time. Such studies normally treat corruption as a phenomenon of public officials taking private advantage of their public offices, but recognize that both public and private figures are typically involved. ${ }^{1}$ Public officials tailor or administer laws, regulations, contracts, and other policies in ways calculated to benefit particular private interests in return for bribes (or other sorts of personal material gain). Such arrangements may be good for the public officials and the particular favored private interests, but bad for overall economic performance (and social welfare) if they contribute to: misallocation of resources (public or private); irregular protection of property rights that deters individuals from exerting effort or investing in physical or human capital; or barriers to entry or other impediments to competition, innovation, and use of best $_{\text {practice. }}^{2}$

There seems little disagreement that, in theory, higher levels of corruption should impede economic performance, but empirical investigation of this relationship has been largely confined to establishing strong correlations in contemporary data. This work has been very informative,

\footnotetext{
${ }^{1}$ In some contexts, fraud, or deceit or cheating between private parties, might also be considered a form of corruption. However, in the modern literature this class of activities are generally viewed as a consequence of poor enforcement of the 'rule of law'.

${ }^{2}$ Daniel Kaufmann and his colleagues at the World Bank have been pioneers in trying to devise systematic measures of corruption, and relating it to performance, at both the micro and macro levels. See, for example Hellman, Jones, and Kauffmann (2000). Also see La Porta, et al. (1999); Murphy, Shleifer, and Vishny (1993); Shleifer and Vishny (1993); and Glaeser and Shleifer (2003).
} 
but skeptics argue that the results might be due to high levels of productive performance reducing corruption, either through institutional change or though affecting perceptions, rather than by reductions in levels of corruption bringing about better economic outcomes. For this reason, it is not surprising that many scholars are turning to economic history to improve our understanding of the social processes involving corruption. Extending the study of corruption along a time dimension offers the possibility of obtaining a more precise fix on the importance of corruption for understanding long-run patterns of economic growth or performance more generally. It should also allow for a closer examination of what sorts of conditions are more conducive to corruption, whether the forms of corruption change over time as circumstances change, whether some forms are more destructive of prospects for economic progress, and of whether (and how) specific types of institutions or conditions reduce the prevalence of corruption.

Although the study of corruption may be much enhanced by turning to history, several key problems remain. The first is definition. Where does one draw the line between corrupt and non-corrupt behavior? Can an action that is legal be corrupt? Should private actions that deviate from meritocracy or economic efficiency, and systematically advantage or disadvantage a particular agent or group, be considered corrupt, or should the classification be reserved for behaviors involving public officials? If the latter, should the standard for corruption be the familiar "taking private advantage of public office," and if so, what does private advantage encompass? Should any action by a public official that affects the interests of a party with whom the official has a personal or pecuniary relationship be so classified? The second problem is one of measurement. Even if one is able to formulate a definition that is conceptually sound, how does one empirically implement it such that study of how corruption varies over time, place, and other circumstances is feasible? 
Recognizing the difficulty of framing a broadly acceptable general definition of corruption, we choose to focus our study of corruption on a specific context - the building of the Erie Canal, and other canals, by New York State during the antebellum period (see Figure 1 for a map of the New York State canals and the railroad system c.1858). The logic of this approach is that it will be easier to develop a reasonable working definition of corruption in a particular setting, and our goal is to explore the issue of whether corruption in this major public works program of the era led to a marked misallocation of resources, generated excess rents for the well connected and politically influential, or otherwise constituted a significant obstacle to economic growth. Large-scale public works projects such as the Erie Canal (which was sometimes referred to as the "big ditch") are widely regarded as nurseries for, if not hotbeds of, corruption. Well-directed bribes (varying in form), or clever orchestration of logrolls, can generate appropriations for public investments whose social returns would not seem to warrant the costs that the respective population has to bear. Moreover, even for projects having a solid economic basis, problems in governance, or principal-agent issues more generally, provide opportunities for public officials to extract personal returns at public expense through the precise design of the plan (such as the route of the canal) and the manner in which contracts for construction or operations are extended, written, and enforced. Thus, overall economic performance can be impacted adversely from excessive investment in public works, poor project selection, public authorities agreeing to higher than necessary costs in carrying out the work, as well as by the dissipation of resources in rent-seeking and other secondary effects.

The movement by a number of northeastern states during the first half of the nineteenth century to undertake the construction of a massive network of roads, canals, and railroads, in an attempt to attract and gain control of trade with the Midwest, is perhaps the most dramatic 
example of the intense competition among states that the federal nature of U.S. government encouraged. ${ }^{3}$ Boston, New York, Philadelphia, Baltimore, Washington, and New Orleans (as well as Montreal) all sought to tap the midwestern trade, and did so with various combinations of canals and railroads. The great triumph of New York City is what makes the Erie Canal (but some might say it is the reverse) a critical part of the American historical experience. Much attention, deservedly, is given to its successful construction and operation as one of the success stories among state economic policies. Less attention has been devoted to the importance of political factors in its origins, and to the blemishes in the story of its construction. While clearly a great success and one of the leading reasons why New York City became the principal port of the U.S. and upstate New York a major agricultural and industrial center for a century, questions about the prevalence of corrupt practices in the development of the Erie Canal and other canals were raised during the era.

There has been a considerable historical literature devoted to corruption in the economy in the postbellum United States. Colorful terms such as "The Robber Barons," "The Great Barbecue," and "The Gilded Age," have been applied to the late nineteenth century links between government and the economy, and texts are filled with the story of the Union Pacific, the Chapters of Erie, and the great battles among the railroad tycoons seeking advantageous routes and rates. Curiously, however, despite some attention to the operation of the so-called "spoils system" and legislative bribery in chartering banks and other businesses, many scholars have treated the antebellum era as relatively corruption free. There are, of course, discussions of the background to Hamilton's economic policies, especially the assumption of the state and central government revolutionary war debts by the federal government, and the Yazoo land scandal is

\footnotetext{
${ }^{3}$ In addition to the works cited elsewhere in this article, for recent discussions of the general movement
} 
depicted by some as symptomatic of other land speculations, but the general impression is that corruption was, if not less prevalent, less costly than in later years. ${ }^{4}$ In part, this may reflect the fact that governments were smaller during this era, and that most of the relevant activity took place at the state and local levels, rather than federal. The perspective of corruption not being such a problem during the early nineteenth century also traces back to Tocqueville, with his emphasis on high rates of citizen participation in (and monitoring of) local affairs, competition between different communities and states (as well as political figures and parties), and an ideology celebrating democracy and open access. In such a setting, one might expect opportunities for rent seeking to be rather limited. ${ }^{5}$ Whether this judgment reflects the reality, or whether corruption by large railroads and manufacturing firms merely provides a more exciting story than those forms of corruption that occur in smaller decentralized polities, is an issue deserving of more investigation.

Recently Edward Glaeser and Andrei Shleifer have asked whether this view that corruption was not so severe during the early years of the republic is well founded. ${ }^{6}$ In suggesting that the traditional image is idealized, if not mistaken or naïve, they are raising for internal improvements in transportation, see Shaw (1990); Majewski (2000); and Larson (2001). ${ }^{4}$ On the Yazoo scandal, see Magrath (1966), and for a discussion of the debates on the assumption of the debts, and other aspects of the Hamiltonian policy after the Revolution, see Nettels (1962), pp. 89-129.

${ }^{5}$ See Tocqueville (1961), particularly chapters 5 and 8. Another related and relevant feature of antebellum political structures in the U.S. is the extremely high turnover rates of elected representatives. L. Ray Gunn (1988) argues that the extremely brief tenures of legislators during the early- and midnineteenth century led to legislatures that were focus primarily on local and sectional concerns, as committees were weak and legislators closely tied to their communities, "The legislature mirrored an increasingly fragmented, mobile, individualistic society, which seemed to drive its very energy from the competitiveness of local communities. As a consequence, policy demands were themselves highly fragmentary, representing local or sectional interests and only rarely expressing the possibility of a 'general' interest. Thus, the legislature more nearly approximated a public market in which the agents (legislators) of local and special interests bargained and traded for considerations favourable to their clients (constituents) than a deliberative assembly making public policy for the common good... But it should be noted that this was a wholly acceptable, indeed desirable, condition in the context of American ideas about representation." See Gunn, p. 80. 
fundamental questions about the nature of the relationship between corruption and economic development. Are high levels of corruption so detrimental to prospects for economic growth that developing societies must focus on reducing them if they are to have much hope of realizing sustained material progress? Or is pervasive corruption a feature or symptom of a pre- or earlyindustrial society that will decrease with economic growth as higher incomes support changes in institutions that lead to improvements in 'rule of law'? The case of the U.S. has often been cited in arguments that low levels of corruption, or secure property rights, are a virtual precondition for sustained growth. ${ }^{7}$ The provocative notions of Glaeser and Shleifer challenge economic historians to determine just how prevalent corruption was during the antebellum period. Our work is but one part of a general effort to respond to that challenge by extending our knowledge of the record of corruption in the American past.

The paper is organized in a straightforward fashion. The next section reviews the history of the building of the Erie Canal, and of how the enormous success of this unprecedented public investment in transportation infrastructure inspired more public investment in canals, in New York and elsewhere. We note how the administrative procedures adopted for the letting and monitoring of contracts in constructing the Erie Canal do appear to have led to rather effective use of public funds, but that the oversight of public resources may have eroded during the canal mania that followed. In the third section of the paper we make use of the ratio of actual expenditures on public works relative to the original projected costs as a gauge of the quality of governance of public resources. We contend that the ratio is a useful measure of an important phenomenon closely related to corruption, and that it has the additional advantage of permitting

\footnotetext{
${ }^{6}$ Glaeser and Shleifer (2003).

${ }^{7}$ For examples, see North (1981) and Rosenberg and Birdzell (1986).
} 
comparisons over time and other circumstances. ${ }^{8}$ Estimates of the ratio for a range of public works extending from the Erie Canal to the present day are presented, and it is shown that cost overruns seem to be much larger (in absolute and relative terms) in the modern era than during the early nineteenth century. In the concluding section, we note how a comprehensive study of the governance of resources in public works would examine the social rates of return on investment, but that our evidence points to the possibility that the governance of public works projects may be worse today than it was before. The significance of this finding is, moreover, bolstered by the observation that the government has come to play a markedly more substantial role in the economy than it did previously.

\section{II}

Canals were only one of a large range of economic activities, most notably in the provision of social overhead capital, provided or permitted by state governments during the antebellum era. Unlike the railroads that would come later, canals were generally both built and operated by governments. Railroads were granted state charters (allowing them to raise funds in the private capital markets that only gradually evolved over time) as well as awarded subsidies in the forms of land, bonds, or cash, but most were privately owned, built, and operated. Given the central role of government in canal construction and operation, as well as the pronounced geographic patterns of the benefits they yielded, it is easy to understand how the political factors involved in making decisions and in obtaining the necessary votes to implement them could have led to overbuilding of canals, which raised overall costs even in the absence of outright fraud and

\footnotetext{
${ }^{8}$ This interpretation is not unique to us. Susan Rose-Ackerman (1999, p. xi) has commented: "People [at the World Bank] told me that when a review of a program mentioned "governance problems," "unexplained cost overruns," or "excessive purchase of vehicles," this meant that corruption and simple
} 
corruption. With so many parts of New York State desirous of procuring access to low-cost water transportation, how was the route of the Erie Canal (and other canals) selected? How was legislative approval of the plan for the rules and regulations controlling the actual construction and operation of the canal accomplished ${ }^{9}$

The great commercial success of the Erie Canal and its contribution to the growth of New York City often leads us to overlook the uncertainty and political controversy that surrounded the project. Not only was the Erie Canal a public project of an unprecedented scale (363 miles) and cost to society, but the route was also not the obvious first choice for a canal to link the Midwest and Lake Erie with the Hudson River. ${ }^{10}$ Apparently, the shorter, cheaper and more certain route would have linked a canal around Niagara Falls with another leaving Lake Ontario for the Oswego River. Indeed, this was the approach recommended for New York State by Albert Gallatin in his 1808 Report on Canals, where he otherwise did an excellent job in detailing a plan for the antebellum canal network that would ultimately be constructed. ${ }^{11}$ There was a strong logic for the Erie route, however, especially from the point of view of the state government (see

theft were a problem."

${ }^{9}$ Our descriptions of the debates over the building of the Erie Canal, and of the discussions of various forms of alleged corruption are drawn from our reading and examination of a variety of primary and secondary sources, including: Documents of the Assembly of the State of New York (1847, 1851, 1868, 1875, and 1876); Reports of the Commissioners (1818); Laws of the State of New York (1825); Whitford (1906); Renwick (1842); Hunt's Merchants' Magazine (1852); Hammond (1846); Shaw (1966); Walker and Walker (1963); Sheriff (1996); Miller (1962); Hanyan and Hanyan (1996); Goodrich et al (1961); and MacGill and others (1917).

${ }^{10}$ George Washington is often credited with suggesting, during the 1780 s, a canal to link the Great Lakes to Atlantic ports. The route ultimately selected was extraordinarily ambitious, however, in that no canal of near that length had previously been constructed in either Europe or the Americas. Although there were many short canals in England, by far the longest was in France, a 148-mile long waterway in Languedoc - spanning less than half the distance the Erie did. The longest canal in the Americas extended for less than one-tenth the length. See Goodrich (1960) for more discussion.

${ }^{11}$ The building of a link between the Hudson and Lake Erie similarly presented a choice of methods. Clinton advocated a waterway, while Morris - another powerful member of the State Commission favored an inclined plane-canal from Lake Erie to Utica, and then a connection with the Hudson via the Mohawk River. This approach was dropped in 1816 however. 
Map). Not only was there a possibility that the canal Gallatin proposed might lead to a diversion of midwestern produce to Canada (Montreal), not New York City, but the Erie route also had the advantage of having a higher expected payoff because of the considerable new land in western New York that it would bring into profitable production. Indeed, the funding of the Erie Canal was aided by substantial land grants from the Holland Land Company, and others, as an inducement to build the canal through their lands.

The Erie Canal was well short of being voted in unanimously, as the issue came to be entangled in sectional and political disputes. Indeed, the margin of victory in the 1817 roll call was very thin. The mid-Hudson valley farmers were opposed to the canal because of the threat of extensive Midwestern and upstate produce entering into New York City. The quite strong opposition of New York City is a bit more difficult to comprehend. In part, given the great uncertainty of whether the stimulus to economic development would be sufficient to justify such a massive public work - more than twice as long as the then longest canal in the western world and more than ten times that in the United States at the time - economic success (or even its completion within a reasonable time) was not obvious beforehand. Even Thomas Jefferson, whose boldness and vision were reflected in the Louisiana Purchase, in 1808 considered the project a century ahead of its time. ${ }^{12}$ With those in New York City fearful that they would bear a heavy tax burden for a social investment with little return, it should perhaps not be so surprising that their representatives stood fast against the construction of such a large-scale public work. A second reason for the lack of support from New York City reflected the intense political disagreements within the state. With De Witt Clinton (who became governor in 1817) and his Federalist followers pushing vigorously for the canal to generate economic growth, as well as to

\footnotetext{
${ }^{12}$ See Shaw (1966), pp. 35-37. Granted, Jefferson expressed this opinion when reneging on an earlier
} 
further his political interests, the Democrats, then in control of the city, were instinctively opposed so as to prevent any political credit accruing to their rival party. Political struggles of this sort, between representatives from different regions and parties, continued in subsequent debates over expenditures on canal construction, repair, and enlargement, as well as over political patronage of canal employment.

A key issue was, of course, how to finance the canal. While the federal government had earlier indicated a willingness to provide support for interstate public works, a formal request for assistance from New York State was rejected by the national government on the grounds that funding the project would be inappropriate because the benefits would go to residents of only a limited area. New York then organized a petition asking for a general program to help states finance public improvements, but this too was turned down. New York State also attempted to raise funds from those states, such as Vermont, Kentucky, and Ohio, that could expect to benefit from building the canal, but the effort yielded only moral support. Finally, in April 1817, six weeks after President Madison had vetoed legislation that would have provided New York with some funds, the state legislature adopted a measure calling for the building of the canal and accepting that New York State would bear full responsibility; the first dirt was dug on July $4^{\text {th }}$. The five canal commissioners (previously appointed under an act of 1810) that had prepared an extraordinarily detailed plan, including the route, technical specifications, and estimates of cost, were vested with the authority to direct the construction and to borrow the money on the credit of the state. The law provided that this debt would be paid off from a Canal Fund, overseen by all of the officers of the state except the governor. The revenues for this fund were to come from tolls from the canal, a tax on salt manufactured in the state, duties on goods sold at auctions, a 
tax on steamboat passengers, grants, donations, and a tax on real estate located within 25 miles of the canal (this latter tax appears never to have been implemented). The need to levy taxes within New York State led to inevitable conflicts between those who expected to receive direct benefits and those who expected not to benefit, as well as over how to tailor revenue enhancements. For example, an initial proposal to raise funds through a more general tax on property was voted down.

One method of attracting votes from the representatives of districts not in a position to directly benefit from the canal was the use of traditional logrolling to provide assurances that their support would be remembered in decisions about future, if not concurrent, transportation projects. Extensive legislative maneuvering was required to obtain approval of the act to construct the Erie Canal, contributing to the inclusion of authorization to build the Champlain Canal (linking the Hudson to Lake Champlain) in the 1817 act. However, logrolling seems to have played a much more important role after the completion of the Erie and Champlain, as a mania for canals developed and the legislature authorized surveys for seventeen proposed canals in 1825 , and the actual construction of five additional shorter canals over the next decade. ${ }^{13}$ It has been widely noted that the geographic patterns of voting on the various bills were salient, and that the question of whether a proposed canal would traverse near the home county explained more about how legislators voted than did their party affiliation or the advice of state officers about financial feasibility. ${ }^{14}$ Representatives of counties along the Erie Canal were

\footnotetext{
${ }^{13}$ By 1836, even after two reductions in tolls, the Canal Fund was able to pay off the entire debt incurred in building the Erie and Champlain canals. The five lateral canals included the Oswego Canal (begin in 1825 and completed in 1829), the Cayuga and Seneca Canal (1827 to 1828), the Crooked Lake Canal (1829 to 1833), the Chemung Canal (1829 to 1833), and the Chenango Canal (1833 to 1836).

${ }^{14}$ See the discussions in Hammond (1846) and Sowers (1914) about voting patterns. A telling example of the weight of economic feasibility in the deliberations of this period comes from the case of the Chenango Canal. Despite a report from the canal commissioners stating that its tolls would be unlikely
} 
understandably reserved or hostile to new projects that were thought likely to offer competition for traffic. ${ }^{15}$ Three of these five extra waterways proved to be (as anticipated) financial failures, and added to the state's debt. Indeed, in 1876, the New York Canal Investigation report notes, that "the lateral canals, [has] been the sole cause of the fact of the present indebtedness of the State by reason of the canals." 16

As inefficient (or corrupt) as logrolling might seem, this approach to getting measures through the legislature was, and remains, far from novel. Logrolling along geographic lines was a common feature of crafted political alignments throughout the antebellum period, wherever (most notably Pennsylvania, Ohio, and Kentucky, as well as New York) there was legislative consideration of internal improvements. ${ }^{17}$ When successful (from the perspective of those seeking to obtain authorization for an economically desirable public investment), logrolling meant that there were higher costs than necessary to construct the core project. ${ }^{18}$ A failure to achieve success by logrolling saved on costs to the state government (by avoiding the commitment of public resources), but often - because of the difficulty of raising private funds to carry on with the investment - meant the loss of the benefits that would have flowed from the internal improvement. In a context of legislators voting the interests of their constituents, logrolling may not merit classification as an intrinsically corrupt practice. Rather, the key issue

to cover either the interest on the debt necessary to construct the canal, or the variable costs of operating it, and warnings from the state comptroller and the governor about its inadvisability, the legislature ultimately voted to order the canal commissioners to proceed with construction.

${ }^{15}$ In a similar fashion, once the Erie Canal was built, Clinton and Martin Van Buren, who had both vigorously pursued federal support, reversed their stances and systematically opposed federal aid for internal improvements. See Seavoy (1982), pp. 3 and 83.

${ }^{16}$ See Report (1876), p. 11. The report continues: "but for that fact, the State would be to-day entirely free from any canal debt."

${ }^{17}$ For discussion of the experiences in Pennsylvania and Ohio, see Hartz (1948) and Scheiber (1969).

${ }^{18}$ Of course, there may be cases where no economically desirable public investment is at stake, and success at logrolling leads to allocating resources to a set of socially undesirable projects. 
about logrolling is the social return to the package of public investments for which the political tactic obtains authorization.

Payment of bribes to secure approval of the Erie Canal was not mentioned in the extensive legislative hearings on the construction and operations of the canal, nor in the many scholarly treatments of this major public works project that have been published since. In contrast with descriptions of bank charters being issued during this era in return for bribes, in cash or by sale and repurchase of securities, exchanging votes for remuneration seems to have been insignificant in this case, perhaps because of the opportunities for land ownership in appropriate locations. Where corruption and fraud were more visible concerns of the state, or of those entrusted with responsibility for public funds, was in the construction and operation of the canal. Rather than have the work done by state employees, the policy was to contract out the construction to private firms or individuals who furnished their own tools and hired their own workers. A rather small group of engineers (most of whom were canal commissioners) was responsible for most of the technical or design issues, and they and their assistant engineers oversaw the work of the various contractors. Partly because the enterprises of the era were of modest size (and often strapped for funds to procure necessary supplies and materials), each contractor was to handle only a short stretch of the canal (no more than a few miles, and sometimes as short as a quarter-mile). ${ }^{19}$ This policy also meant that expenditures were widely spread to benefit many contractors in local areas, a non-trivial consideration during the protracted economic contraction that plagued the country through the early years of the project (up until

\footnotetext{
${ }^{19}$ Each contract was to be put up for bid, and assigned to the lowest bidder, and contained detailed specifications appropriate to the individual situation (with the tasks including clearing land, excavating, and the construction of locks, embankments, culverts, towpaths, fences, etc.). For more treatment of the procedures, see Shaw (1966) and Walker and Walker (1962), pp. 40-44, for the relevant discussion from the 1818 Report of the Commissioners.
} 
1821 or 1822 ). The engineers who were charged with inspecting and approving the quality of the work before the contractor was paid (generally on a monthly basis, and in advance conditional on performance up to that point), typically boarded at homes near the construction site and made their disbursements in small bills drawn from local banks. ${ }^{20}$

Although a theory for why this organization of the construction would keep costs low was offered by some observers at the time, the basic reason for its adoption was likely the reality that the work was performed over a vast geographic expanse, and that construction firms of this era were small and highly localized. $^{21}$ It was, accordingly, left up to the engineers responsible in each area to provide for construction by placing for bid contracts pertaining to rather short spans. On one hand, the lack of central control and monitoring of contracting procedures, the small size of the firms hired, and the not uncommon personal familiarity between the engineers and the contractors could well have fostered corrupt practices. From another perspective, however, it could be argued that the conditions were unfavorable to malfeasance. Not only did the technology of constructing canals make it relatively easy to make comparisons of cost per mile across supervising engineers or contractors, and to detect those stretches of canal that were below standard (further facilitated by strict procedures and guidelines for the testing of the quality of the work), but the absolute amounts to be gained from individual episodes of corruption must have

\footnotetext{
${ }^{20}$ The most prominent scandal associated with the construction of the canal concerned the activities of Myron Holley, the treasurer of the Canal Committee, and the commissioner who was perhaps most active at negotiating contracts and disbursing payments to contractors. Although attacked by some observers for partisanship in the award of contracts as early as 1820, in 1824 it was discovered that he was unable to account for $\$ 30,000$ of public monies, and had used public funds to purchase property near the canal. For more discussion, see Shaw (1966), pp. 169-172.

${ }^{21}$ Another explanation for the use of relatively small contracts rather than a sole, general contractor emerged during the Progressive Era, with the intent to curb the powers of contractors and avoid corruption on public jobs, albeit at the cost of imposing difficulties of coordination. While many states soon repealed this legislation, New York still operates under the Wicks Law, which requires separate contracts for each function to be performed.
} 
been small.

A ceremony to officially mark the completion of the entire canal took place to universal acclaim in 1825 , but the financial and economic success of the Erie was evident to observers well before. Indeed, it was not long after the middle section of the canal had been opened, and substantial toll collections began to roll in, that the securities issued to mobilize funds for the remainder of the project were attracting the interest of investors as distant as London. The primary basis for the enormous social returns to this public investment was of course the demand for the transportation services that the canal provided at radically lower cost than the alternatives. ${ }^{22}$ But the cost effectiveness of the construction effort also deserves attention. Despite the massive and unprecedented scale of this public works project, the provincial attitudes of most of those involved, and the direction by canal commissioners who were at best self-taught engineers, the Erie Canal (and its companion Champlain Canal) were constructed at only about 46 percent above the estimated costs at the time of authorization. Although this overrun seems quite formidable in the abstract, it is (as suggested by the comparison with other public works project presented in Table 1) quite modest by the standards of modern experience and sensibilities.

The problems of excess expenditure, if not corruption, in New York State grew much more severe after the completion of the Erie. As mentioned above, the Erie Canal was so successful in stimulating economic development along its route, and in generating surpluses from tolls, that state legislators were swept up with a general enthusiasm for constructing many more

\footnotetext{
${ }^{22}$ See Fogel (1979) for discussion and estimates of the extraordinary cost advantages of canals and railroads over transport by horse and wagon. More specifically, the costs for transporting grain or flour from Buffalo to New York City are generally said to have fallen by 85 to 90 percent. So great was the impact of the Erie Canal, that Carter Goodrich (1960, p. 55) judged its opening as "the most decisive single event in the history of American transportation".
} 
canals throughout New York with borrowed funds. ${ }^{23}$ Within five years, they authorized going forward with a series of additional canals despite reports from canal commissioners that predicted that at least some of the planned canals would not produce sufficient tolls to cover expenses, and a series of increasingly tough warnings from the comptroller and governor about committing to projects unlikely to be able to cover costs. To make matters worse, as the annual expenses of the state government grew over time, the legislature, reluctant to raise taxes, increasingly relied on tapping the revenue or accumulated surplus from canal tolls and exotic financial measures such as borrowing from the Common School Fund at lower than market rates. Despite the ominous fiscal balance, however, in 1835 and 1836 the legislature again defied the advice of the governor by authorizing not only a major enlargement and improvement of the Erie Canal (which was widely acknowledged to be of insufficient size given the heavier than expected volume of traffic) but also several other waterway projects and a $\$ 3$ million loan to aid the New York and Erie Railroad. ${ }^{24}$ Even with a change in the party in power (from Democrats to Whigs), a courageous and insightful state comptroller, and the encouragement to concentration of the mind provided by the financial crisis of 1837 and the protracted downturn that followed (along with the associated fall in canal revenue), the legislature continued to pursue policies of extravagance. The ability of the state to service its debt and obtain new credit, not coincidentally, eroded dramatically.

It was not until 1842 that New York, on the brink of insolvency, began to take strong

\footnotetext{
${ }^{23}$ It is interesting that this movement to build more canals got started about the same time that the franchise was extended in New York by eliminating wealth requirements. See Engerman and Sokoloff (2004).

${ }^{24}$ For discussion, see Shaw (1966), pp. 239-242. For more on the New York and Erie Railroad, see Pierce (1953), pp. 13-16.
} 
action. ${ }^{25}$ The "stop and tax law of 1842" both assessed a general tax on wealth as well as suspended state expenditures for the construction of public works (only maintenance and repairs). As the state made progress in paying down its debt and restoring fiscal balance, it also took steps to prevent the recurrence of such profligacy by the government. In 1846 a new constitution was adopted, and among the many important new provisions were restrictions on borrowing, establishments of guidelines for the use of sinking funds to pay off canal and other government debts, and other reforms directed at improving governance. ${ }^{26}$ The same concern with trying to identify the sources of the fiscal crisis, as well perhaps as a spirit of reform more generally, also gave rise in 1846 to the first serious investigation of the construction and operations of the canals. Another motivation may have been an interest on the part of legislators to shift responsibility for the debacle in state finance.

The Select Committee of the Assembly convened in 1846 was zealous about "investigating frauds in the expenditures of the public moneys upon the canals of this state," and desirous of identifying problems that would attract public attention and provoke enactment of, if not resolution by, new laws and procedures. ${ }^{27}$ The investigators focused on the possibilities of corruption associated with the construction of the canals as well as on the use of canal-related jobs as a form of political patronage (with the allocation of supervisory, inspector, and other positions associated with operating the canals changing with shifts in parties in power). The

\footnotetext{
${ }^{25}$ During the early 1840 s, one-third of the states defaulted on their bonded debt, and while several resumed payments of interest and principal within a few years, four repudiated their debt. See McGrane (1935). New York did not default.

${ }^{26}$ For example, the new constitution increased transparency (and perhaps limited logrolling) by specifying that private or local bills could not deal with more than one subject, and that the subject had to be expressed in the title. Also, money could only be paid out of the treasury "in pursuance of an appropriation" and that any such appropriation had to be explicit about the sum appropriated and the object to which the fund would be applied. See Sowers (1914), pp.72-74 for more discussion.

${ }^{27}$ Report (1847), p. 3.
} 
chronological scope of the inquiry was broad, extending back to the construction of the Erie Canal several decades before. The major sources of corruption highlighted in these hearings were: fraud in allocating contracts to "friends, acquaintances, and neighbors," forging of vouchers for reimbursements of materials, padded payrolls, stolen materials, and use of claims concerning the need for extraordinary repairs to circumvent state limits. ${ }^{28}$ The committee established that problems emerged very early in these public works projects. As noted above, the most notorious example involved Myron Holley, one of the first canal commissioners, who in 1824 had been charged with (and admitted to) being unable to account for some public funds and using some of them to purchase land in the canal region. Also worthy of note was the discovery that the books of the canal commission for the period 1822-1828 were missing (or that no records had been kept during those years), and that several of the individuals asked to testify about the construction of the Erie declined to do so.

What stood out in these hearings, and in the other major hearings that were to be held in the years to come on the subject of the construction and operations of the canal policies, is that the quality of controls had become more lax over time, allowing the influence of politicians (as regards who served as engineers and who received contracts) and corrupt practices by engineers to become more pronounced. ${ }^{29}$ Although other factors, such as the originally unscheduled

\footnotetext{
${ }^{28}$ Report (1847), p. 6.

${ }^{29}$ For example, the report of the Select Committee expressed concern about what happened under the charge of Frederick C. Mills, chief engineer on the construction of the Genesee Valley Canal. Near the close of his work, his brother Hiram P. Mills was employed as resident engineer on the stretch of the canal extending from Mont Morris to Olean. The contracts for the construction on this part of the canal were let in the fall of 1838: "It will therefore, be seen that the work on that section was immense, and that a majority of it was rock excavation from the mountain side, whence the rocks excavated could be cast directly off into the river channel. The contract for that work being a very desirable one, there was much competition for it; and the manner of conducting the business of letting that contract to the successful competitor, deserves particular attention. The contract was awarded to Nicholas Van Derwerken, who it is said, was not possessed of the means necessary to the prosecution of such an undertaking, and who was
} 
cessation of construction between 1842 and 1847, certainly played an important role in accounting for cost overruns, the findings of the investigators suggest that poor governance (encompassing acceptance of incompetence or inefficiency), if not an increased prevalence of outright fraud, help to explain why the costs of enlarging and improving the Erie Canal ballooned from the initial projection of $\$ 12.42$ million to over $\$ 30$ million (and the time required for the work from 12 years to 27 years). The testimony to, and analysis provided by, the series of investigating committees convened by The New York Assembly and/or Senate were published in 1847 (1242 pages), 1851 (332 pages), 1868 (1018 pages), 1875 (677 pages), and 1876 (770 pages), and in less complete reports on contracts and frauds in other years (starting in 1840). ${ }^{30}$ The 1876 Report reported on the following "various forms of mismanagement, neglect, fraud, and malfeasance":

(a): the approval or toleration of 'unbalanced bids'; (b) improper action of commissioners in making new contracts, and in extending or canceling old ones; (c) agreement to contracts that were adverse to the interests of the State, and for the benefit of contractors; (d) blind, hasty or corrupt legislation in making appropriations for repairs, claims, and awards; (e) failure of engineers to make true cost estimates, and connivance with bidders or contractors in making false ones; (f) carelessness or neglect on the part of the Canal Board in ascertaining whether proposed work had proper legal sanction; (g) appropriation of property of the State by contractors, or by superintendents; (h) approval, by superintendents, of bad or worthless work; (i) wrongful or careless awards by canal appraisers; ( $\mathrm{j}$ ) the legal fiction of 'extraordinary repairs' which misstates a matter of fact, misleads successive Legislatures, and prevents the completion of the enlargement; and (k) the lack of responsibility on the part of canal officers, owing to a defective system of subdividing duties, which rendered it difficult to hold a wrong-doer to strict account. ${ }^{31}$

The various hearings uncovered a number of instances of these kinds of mismanagement and

without experience as a contractor. How it happened that he became the lowest bidder does not directly appear, except by the proposition itself; but the course then pursued in regard to it by H.P. Mills, the resident engineer, leaves the impression very strong that there was connivance between him and Van Derwerken. After the work was awarded to Van Derwerken on his proposition, the contract for it was taken jointly by Van Derwerken and Robert Powers, his brother-in-law, who had previously been a partner with H.P. Mills." See Report of the Select Committee (1847), pp. 4-49.

${ }^{30}$ See Report (1876), p. 11; and Hasse (1907). 
malfeasance, as well as the likelihood that there had been some confiscation of fees and tolls collected by canal workers. ${ }^{32}$ Their conclusions, framed in general terms, were that the controls intended to prevent behaviors inappropriate or otherwise wasteful in the use of public funds were imperfectly designed, not strictly adhered to, and irregularly enforced. Because we have all come to expect such problems, at least to some extent, in the administration of large public (and private) enterprises, it is in no way surprising that thorough investigations uncovered their existence. What would be more informative and useful, however, is a gauge that would allow us to evaluate the magnitude of these problems, and to examine whether their seriousness varies over type of project or time.

\section{III}

Several features of this record of canal building by New York State stand out. First, although legislators were perhaps wanton in their authorization of public transportation projects, it is significant that a potentially more corrosive form of rent- seeking appears not to have imposed major costs on the state. The legislature does not seem to have been capable of limiting access to low-cost transportation, and in so doing to greatly advantage one specific region or segment of the population at the expense of others - and at the expense of the overall growth of

${ }^{31}$ Report (1876), pp. 12-16.

32 These same sorts of problems with internal improvement projects were noted in other states. For example, in 1840 the Pennsylvania Canal Commissioners listed twenty ways in which "positive proof was obtained to substantiate...charges of attempts to defraud the Commonwealth". In his study of corruption in The State Works of Pennsylvania, Bishop observes (1907a, pp. 229-244) that "we have no assurance that there would have been greater purity under corporate management," and as "public works were used by the political party in power as an invaluable instrument of political corruption, destroying the morale of citizens and squandering the resources of the state." He concludes that "those who are abashed by the present-day disclosures of corruption in the management of cities and powerful corporations, and who therefore sigh for the 'good old days' of political purity, have to face the fact that these did not exist in Pennsylvania ... at least during the period of state ownership and control of public 
the state economy. ${ }^{33}$ On the contrary, even when precarious state finances should have strengthened the case for skepticism about marginal projects, legislators all too often failed to summon up a majority against. Their failure in enforcing such restrictions, or monopolies, on access to low-cost transportation, was not because of an absence of advocates. The representatives of the areas that already had access to canals were generally amongst those legislators who opposed the authorization of new ones along routes that would have competed for traffic. Similarly, they, as well as others who had interests in canal operations, also sought restrictions on the speed of the expansion of a new competing innovation, the railroad. Various limitations were in fact imposed on the railroads when they threatened toll collections on canals, though they were withdrawn in the early $1850 \mathrm{~s} .{ }^{34}$ Partially offsetting such restrictions were, of course, subsidies to encourage the construction and expansion of specific railroads. Excess transportation capacity and collapsing rates were the consequence.

The observation that legislators were not effective at restricting access to transportation by water or rail reflects the fact that the open political system made it very difficult for those geographic areas or companies who sought to obtain and maintain strong competitive advantages, or monopolies, on such a basis. It further suggests that if there were social costs to

works." See also Bishop (1907b) and Bowers (1983).

${ }^{33}$ The liberal policy about authorizing canals is not unlike the policies concerning the establishment of banks and corporations. The passage of free incorporation and free banking acts reduced the ability of the legislatures to create highly profitable monopolies by restricting entry. Because the monopoly rents would have gone in large measure to legislators with the power to charter firms, the free incorporation and banking laws meant that the legislators were accepting a lower stream of rents. The social and political pressures that led to such policies may have narrowed the scope for, and economic consequences of, corruption in the antebellum economy.

${ }^{34}$ See MacGill and others (1917), pp. 353-356. First were requirements that they carry only passengers, and passenger baggage, not freight. They were followed by restrictions against railroads operating during the summers when the canals were open, and finally by a requirement that railroads pay canal tolls for traffic carried. Similar types of restrictions, lasting until 1861, were introduced for railroads in Pennsylvania. See Dunlavy (1994), pp. 79-80 and 138-139. 
corrupt practices in the building and operation of New York canals they likely consisted primarily of excessive costs of construction and/or operations, or from investments in marginal canals that yielded low social returns. It is beyond the scope of our study to estimate the social returns to each of the New York canals, but we would note that the work of Albert Fishlow suggests that the rate of return on investments in New York canals was well above the cost of capital. ${ }^{35}$ His estimates would seem to imply that the overall cost of the misallocation of public funds on these canal projects was likely not all that monstrous.

Our focus is instead on the issue of whether, and by how much, corrupt practices or incompetence tolerated by public officials increased the costs of constructing the canals. Precise measures of this theoretical concept are of course difficult to tease out of the data. The approach we employ here is to use the ratio of the expenditures on public works projects relative to the estimated cost at the time of authorization as a rough gauge of the quality of public governance in such activities. This ratio is, of course, very different from the amount by which the costs of construction exceeded the minimum feasible cost, but it has the advantages of being both relatively straightforward to retrieve as well as meaningful about the quality of public governance. ${ }^{36}$ The implicit supposition for our approach is that conscientious public officials practicing good governance would make their decisions about whether to go forward on a public investment with the best available estimates of costs (and benefits). Errors in these estimates are

\footnotetext{
${ }^{35}$ Fishlow (2000), pp. 552-564, and pp. 604-606. See also Goodrich et al (1961), pp. 216-247; and MacGill (1917). The social and private returns on building the Erie Canal were much larger than on the others, but in his assessment of six of the New York canals, Ransom (1964) concluded that three of the six were "successful" in financial terms. Fishlow also judged the early canals in Ohio successful. The problem was that too many feeder canals (like in New York) were built. Competition between the large number of waterways and railroads put substantial downward pressure on tolls.

${ }^{36}$ How much the ultimate costs of a project exceed the estimated costs at time of authorization, and how that ratio has varied over time and across projects, has been the subject of earlier studies. See, for example, Merrow (1988) and Flyverberg, Bruzelius, and Rothengatter (2003).
} 
obviously to be expected, as it is impossible to perfectly anticipate all of the circumstances that develop in the course of major construction projects, and public officials, like other humans, are often prone to wishful thinking. Nevertheless, the estimated cost of a project at the time public authorities commit to carrying out an investment would seem to provide a reasonable baseline, on average, if there was good governance over public resources. Thus, we argue, a major source of systematic bias in the cost estimates is tolerance of incompetence, weak oversight or administration, actual corruption, and other cost-inflating practices by public officials, or the quality of governance more generally. Deliberate misrepresentation of the costs of a big public investment project reflects poor governance, in that public officials can get away with it (whether they are elected officials or not). Moreover, to the extent that costs rise (on average) after the authorization of a public investment project, it would seem reasonable to attribute it primarily to poor management or oversight of the uses to which public funds are being put - whether due to corruption or tolerance of incompetence and other cost-inflating practices. The measure we rely on, therefore, should be regarded as one that relates more to the quality of public governance than to the level of corruption narrowly understood.

Although we emphasize how the cost overrun ratio is informative about the quality of public governance, it must be admitted that there are other reasons - some quite innocuous - why the ratio might differ from unity or even vary systematically. First, there might be unanticipated inflation, such that nominal expenditures could total more than original forecast, even if expenditures expressed in constant dollars had not risen. ${ }^{37}$ Second, the costs of a public works investment might exceed the projected amount, because of a redesign that added new elements

\footnotetext{
${ }^{37}$ One might initially presume that this issue would lead to substantial cost overruns during periods of inflation. However, often, such as in the U.S. over recent decades, the projected expenditures generally took account of expected inflation in forecasting nominal expenditures. See the discussion in Merrow
} 
that added to costs. A third consideration, one that could in principle lead to increases or decreases in costs, is that technology (or regulations) might advance in unexpected ways. Yet another possible contributor to cost overruns is the deliberate preparation of downward-biased estimates of the costs of projects so as to increase the likelihood of their being approved by public authorities. There might also be problems having to do with management, which may stem from the complexity or scale of projects being undertaken - rather than to the quality of public governance. All of these factors need to be taken into account in the interpretation of any costs overruns, or systematic patterns therein.

As we have already stated, and as is highlighted in Table 1, the seriousness of the cost overruns in the construction of New York canals seems to have increased after the completion of the Erie Canal. Whereas expenditures on the Erie totaled roughly 46 percent more than those projected at the time the legislature authorized going ahead, the ultimate cost of the enlargement and improvement of the Erie was more than 140 percent greater than the plan approved in 1835 (a decade after the Erie was originally opened). That the cost overrun was much larger in the later work is consistent with the evidence of erosion of oversight, and of greater prevalence of corrupt practices, over time uncovered by the various investigations conducted by the New York State Assembly and Senate. At least part of the higher than expected costs of completing this project must have been due to the interruption in work, between 1842 and 1847, brought on by the state fiscal crisis. ${ }^{38}$ It is notable, moreover, that the cost overrun on the Erie Canal improvement project was far greater, relative to the estimated figures at time of authorization,

\section{(1988).}

${ }^{38}$ Although the difficulty of obtaining information prevent us from giving the issue more extensive treatment, it does appear that extreme cost overruns were typically associated with delays in completing the respective projects. The Mississippi River Levee Line and the Boston Central Artery/Tunnel projects are examples of projects whose construction fell well behind schedule, and the Hoover Dam is an 
than those incurred on several other antebellum canals - the Chesapeake and Delaware Canal (63 percent) and the Ohio and Miami Canals (16 percent) as well as on the major project that vastly expanded the supply of fresh water to rapidly growing New York City - the Croton Aqueduct.

Given that these canal projects were extremely large, relative to the scale of enterprise, the depth of capital markets, and the size of the economy, the increase in the costs of carrying out these works could not have been insignificant in absolute terms. But it is difficult to gauge the import of the cost overruns without some basis for comparison. For this reason, to aid in the evaluation of the significance of the cost overrun ratios for the Erie and other antebellum canal projects, Table 1 also includes the ratios calculated for other large public works projects over the course of the history of the United States. ${ }^{39}$ Our selection of the public works to include in the table was not random, but we sought to retrieve the information on a range of well-known projects extending from the canal era to the present day. ${ }^{40}$

The record of cost overruns on public works revealed in Table 1 suggests that the construction of the Erie Canal, and of other public works built during the antebellum period, was not plagued by extraordinary problems in managing costs. On the contrary, the cost overrun ratios drawn from the period before the Civil War are generally among the lowest we have observed; only the Hoover Dam, a Great Depression-era public works project does as well by this

example of one completed well ahead of schedule.

${ }^{39}$ Some may find it interesting that the cost overrun ratios we computed for the unsuccessful French effort to build a canal across the isthmus of Panama, and for the infrastructure Montreal needed to host the Olympics were among the highest we have seen. See Toohey and Veal (2000), p. 77. We confine our attention here, however, to public works in the United States.

${ }^{40}$ We have not included in Table 1 all of the public works for which we obtained cost overrun ratios, but the basic qualitative pattern (and rough quantitative pattern) would be robust to their inclusion. For other examples from the late- $19^{\text {th }}$ and early $20^{\text {th }}$ centuries, and discussion of related issues, see Moulton (1915). Another example, developing as this paper is being written is the increase in the cost of the eastern span of the San Francisco Bay Bridge (which was damaged in an earthquake) being carried out under the auspices of the California Department of Transportation. Although the project is not scheduled for 
gauge (the Panama Canal also does better than the project enlarging and improving the Erie Canal). If there is any trend, it is that cost overruns have become somewhat worse over time, especially after World War II. The cost overrun ratios vary between 1.16 and 2.42 across the five antebellum projects (averaging 1.60), but vary between 4.17 and 19.10 across the four projects constructed since $1950 .{ }^{41}$ The difference in the distributions is indeed very stark. If the ratios do provide a meaningful indicator of the quality of public governance, then the implication would seem to be that conditions were better during the early $19^{\text {th }}$ century than in the late $20^{\text {th }}$ century. As many would find such a judgment surprising, it is necessary to critically assess whether we should believe the trend in our estimates. Although more observations would obviously be desirable, the strength of the pattern we have noted and the general consistency of our results with those of other studies give us confidence that the qualitative result will hold up under further research scrutiny. ${ }^{42}$ For example, Bent Flyverberg, Nils Bruzelius, and Werner Rothengatter have conducted studies of both 258 railway and road projects and large nontransportation projects between 1927 and 1998, and found cost overruns to be generally higher, and often much higher, than what we found for the U.S. during the antebellum era. The cost

completion until 2010, the cost overrun ratio is already at 3.0.

${ }^{41}$ The high ratio for the interstate highway system is especially striking. It appears to have resulted primarily from the initial law being written in an open-ended way, such that it obligated the federal government to pay for many more highway projects than had been anticipated. According to Weingroff (1996), the 1952 Act authorized \$25 million for the next two years to pay for an interstate system on a 50-50 matching basis, between the federal government and the state governments. Within one year, however, the states had built considerable mileage, and the federal share of total costs was $\$ 477.5$ million. We regret that our estimated cost overrun on the interstate highway system public works pertains only to the very early stages of the program. We have not yet been able to obtain the information that would permit us to calculate a cost overrun ratio for the entire system.

${ }^{42}$ From our readings of the histories, the cost overruns, even those of the modern era, seem to be primarily due to higher than estimated costs of carrying out or implementing the designs or work laid out in the original plans, as opposed to the addition of new features to the original plan. The one exception (we can not be sure) may be the cost overrun on the interstate highway program. See the sources cited in the note to Table 1 for more details. 
overruns, moreover, seem to have grown slightly over the period under investigation. ${ }^{43}$ In his study of 52 major investment projects (most of which were in mining, manufacturing, and energy) carried out across a range of countries during the 1970s and 1980s, Edward Merrow (using a concept or procedure that produces lower estimates than our approach) found overruns of 88 percent in real terms on average, and markedly higher for public or mixed public-private projects than for private. ${ }^{44}$ Although such estimates of cost overruns on late- $20^{\text {th }}$ century public works projects generally fall below those suggested in Table 1, they do provide rather strong support to our key observation - that such cost overruns were typically lower in the antebellum era than they are today. ${ }^{45}$ Another issue in interpreting the high cost overrun ratios in the modern public works projects is whether the higher rates of inflation during the 1970s and 1980s may lead them to overstate the increase in the real costs of a project over what was originally forecast. This problem may be relevant for assessing the estimated cost overruns for the Louisiana Superdome, the renovation of Yankee Stadium, and the Boston Central Artery/Tunnel project, but in all of these cases no reasonable adjustment for changes in the price level could alter the qualitative finding. ${ }^{46}$

\footnotetext{
${ }^{43}$ See Flyverberg, Bruzelius, and Rothengatter (2003), p. 18.

${ }^{44}$ See Merrow (1988). He and his team calculated cost overruns from the detailed engineering plans typically made after authorization. They also found that projects that were larger ex ante had proportionally higher cost overruns.

${ }^{45}$ Current municipal policies regarding sports stadiums, if not airports and convention halls as well, resemble the mercantilistic policies of local and state governments during the era of internal improvements. This entails competitive bidding for teams and large subsidies to influence location decisions, and has generated intense controversy about the social returns to such public investments. The cost overrun figures we present for several of the earliest public investments in stadiums are somewhat higher than the ones that pertain to more recently constructed stadiums. However, the costs of constructing sports stadiums have ballooned as the mania for publicly-built stadiums has spread. It may be that the commitment of public resources to build ever-more extravagant stadiums for use by private teams on easy terms is the most telling feature in this record about the quality of governance of public resources. See Quirk and Fort (1992 and 1999).

${ }^{46}$ For example, even after adjusting for inflation, the cost of the Boston Artery/Tunnel project more than tripled. See the discussion in Altshuler and Luberoff (2003), chapter 4, and especially p. 119. As the
} 
In our view, the finding that cost overruns on public works were relatively modest during the antebellum era, as compared to those today or in other eras in American history, has a solid empirical basis. ${ }^{47}$ The next and more fundamental question, however, is what this intriguing pattern means.

The straightforward interpretation, one for which we have already expressed support, is that the governance, or control over the use, of public funds was stricter during the early nineteenth century than it is today. It is difficult to explain the more substantial cost overruns during the modern era, in particular, without acknowledging that either the processes of vetting these public works projects were either badly flawed (if not dishonest), or that oversight by the public authorities was so poor as to permit grossly inefficient use or private extraction of public resources. ${ }^{48}$ What the source of this contemporary institutional failure is not easily identified, but task of retrieving all of the information necessary to deflate the expenditures on the public works are quite formidable to us, and as the qualitative results seem likely to be robust, we have not gone any further as of yet. Both the Hoover Dam and Erie Canal projects are cases where the bias from changes in the price level may have served to bias the cost overrun ratio downward, but again the basic qualitative results are unlikely to be sensitive to adjustments for changes in the price level.

${ }^{47}$ Boss Tweed and his New York City machine are not infrequently invoked to illustrate the extent of corruption in the late $19^{\text {th }}$ century United States. It is not clear how representative they were of the country overall, but the histories are rather convincing about how poor public governance in New York City was under the Tammany Democrats. How does Tammany fare under our gauge? Although the complex accounts make it difficult to compute a precise cost overrun ratio, it seems that the amounts paid out for the construction of the famed New York County Courthouse ("the House that Tweed built") were more than forty times the amount forecast at the time of the original authorization (which took place before the Tweed Ring was formed). In contrast, the generally comparable courthouse (as regards size and accoutrements) built at about the same time in neighboring Brooklyn (Kings County) had a cost overrun of only about 40 percent and was built at less than ten percent of the cost of the one in New York. See New York Times (1871) and Callow (1966).

${ }^{48}$ Among the scholars who have examined cost overruns on recent public works and other large investment projects, there are two schools of thought about the principal causes, and the source of the evident trend toward proportionally higher cost overruns. One school emphasizes how forecasts of costs are deliberately underestimated so as to increase the probability of project approval. The notion seems to be that public authorities are less transparent or less able to monitor themselves than they were previously, perhaps because there are a greater number of organized interests that stand to benefit from a project approval and aid public officials in preparing deceptive cost estimates. For examples of those who hold this view, see Flyvbjerg, Bruzelius, and Rothengatter (2003) and Altshuler and Luberoff 
cost overrun ratios during the late twentieth century that seem routinely very high by early nineteenth century standards imply that public officials (or the taxpaying electorate) have lost control. What the basis is for the relatively good performance of the public sector during the antebellum period is likewise unclear.

There are a myriad of possible explanations, ranging from the virtues of democracy and high rates of participation in civic affairs to the natural constraints on corruption and gross incompetence that come along with relatively low per capita incomes and small enterprises (as well as a small government sector). We are as yet unable to distinguish between them, and the absence of information on the social returns to different public works is another reason why our assessment must be considered tentative, but the evidence on cost overruns does seem consistent with de Tocqueville's (1961, orig. publ. 1835) conception that democracy in America meant good governance.

\section{IV}

The Erie Canal was, for its time, a mammoth public works project undertaken largely because the scope of the investment was beyond what a private firm could manage. As with most public works, there were ample opportunities for public officials to realize private gains from the effort, and many did. On the whole, however, the construction of the Erie (and the

(2003).The latter (p. 246) quote Martin Wachs, "one of the nation's most thoughtful and balanced observers of urban transportation policymaking": "I have interviewed public officials, consultants, and planners who have been involved [in transit project cost and ridership forecasting] and I am absolutely convinced that the cost overruns and patronage overestimates were not the result of technical errors, honest mistakes, or inadequate methods. In case after case, planners, engineers, and economists have told me that they had to 'revise' their forecasts many times because they failed to satisfy their superiors. The forecasts had to be 'cooked' in order to produce numbers that were dramatic enough to gain federal support for projects whether or not they could be fully justified on technical grounds." Also see Wachs (1989). Although acknowledging that the much worse performance of public projects was telling, Merrow (1988) argues that changes in the regulatory environment and in feasible technology have also 
companion Champlain Canal) appears to have been well conceived and executed; it not only paid off more than its construction costs through tolls, but also generated substantial welfare improvements for the residents of New York in the form of producer and consumer surplus and a wide range of positive externalities. Although there was obviously some fraud and mismanagement, the public authorities carried out the work at costs relatively close (by the standards of public projects) to those projected at the point of authorization. The experience of the Erie provides something of a model of what a public works project could feasibly be.

The problems arose after the completion of the Erie, and out of a common reaction to emulate success. Noting how the areas along the route of the Erie had grown quite prosperous, many other parts of New York wanted their own transportation improvements. The legislature approved some of the proposals, and committed to building some canals that may have been beneficial to those counties that were served, but whose costs were at least partially borne by taxpayers elsewhere (as toll revenue was insufficient). The consequences of inadequate attention to the amount of traffic that would be procured were compounded by the oversupply of transportation lines as both new waterways and railroads proliferated, and by the impact of a severe and prolonged economic contraction that began in 1837. How much of the misallocation of public funds to such projects should be attributed to corruption or poor governance can be debated, as private agents too often make similar miscalculations in their estimation of the probability of duplicating the success of innovative investments (and did so during this era in buying some of the canal bonds), but matters were made worse by the evident deterioration in cost controls. The resources devoted to the post-Erie projects (both new canals and the enlargement and improvement of the Erie) mushroomed, with the ultimate costs far exceeding 
those originally budgeted for.

In an effort to try to place this episode in a broader perspective, we have computed the ratio of actual expenditures on construction relative to the estimated costs at the time of authorization for the Erie Canal, for the project to enlarge and improve it, and for a range of other public works in the U.S. to the present day. It is our contention that this measure, albeit quite narrow in focus, is informative about the quality of governance of public resources. In general, we expect the ratio to vary positively with the lack of transparency exhibited by public authorities as well as with their level of tolerance of incompetence or other cost-inflating practices manifested in the use of public resources. We highlight how, by this standard, the governance of public resources during the canal era of the early nineteenth century stands up well in comparison with what we have seen since. Indeed, the cost overrun ratios have risen sharply over the last half-century, coinciding with both a marked increase in the relative size of the government sector as well as sustained economic growth. These patterns reveal, in our view, how little scholars and policymakers understand about how the type, prevalence, and effects of corruption vary across different contexts, and how important it is that better measures and other means of systematically studying the phenomenon be developed. 


\section{REFERENCES}

Altshuler, Alan and David Luberoff. 2003. Mega-Projects: The Changing Politics of Urban Public Investment. Washington, D.C.: 2003.

Bishop, Avard Longley. 1907a. The State Works of Pennsylvania. New Haven: Yale University Press.

. 1907b. "Corrupt Practices Connected with the Building and Operation of the State Works of Pennsylvania,” Yale Review 15 (February): 391-411.

Bishop, Joseph Bucklin. 1913. The Panama Gateway. New York: Charles Scribner's Sons.

Bogart, Ernest Ludlow. 1924. Internal Improvements and State Debt in Ohio: An Essay in Economic History. New York: Longmans, Green.

Bowers, Douglas E. 1983. "From Logrolling to Corruption: The Development of Lobbying in Pennsylvania, 1815-1861," Journal of the Early Republic 3 (Winter): 439-474.

Burch, Philip H., Jr. 1962. Highway Revenue and Expenditure Policy in the United States. New Brunswick: Rutgers University Press.

Callow, Alexander B., Jr. 1966. The Tweed Ring. New York: Oxford University Press.

Danielson, Michael N. 1997. Home Team: Professional Sports and the American Metropolis. Princeton: Princeton University Press.

Dunlavy, Colleen A. 1994. Politics and Industrialization: Early Railroads in the United States and Prussia. Princeton: Princeton University Press.

Economist. 2004. The World in 2004.

Engerman, Stanley L. and Kenneth L. Sokoloff, "The Evolution of Suffrage Institutions in the Americas," unpublished working paper.

Frank, Arthur DeWitt. 1930. The Development of the Federal Program of Flood Control on the Mississippi River. New York: Columbia University Press.

Fishlow, Albert. 2000. "Internal Transportation in the Nineteenth and Early Twentieth Centuries." In Stanley L. Engerman and Robert E. Gallman (eds.) The Cambridge Economic History of the United States, Volume II, The Long Nineteenth Century. Cambridge: Cambridge University Press, 543-642.

Flyvbjerg, Bent, and Nils Bruzelius and Werner Rothengatter. 2003. Megaprojects and Risk: An 
Anatomy of Ambition. Cambridge: Cambridge University Press.

Gallatin, Albert. 1968. (first published 1808). Report of the Secretary of the Treasury on the Subject of Public Roads and Canals. New York: Augustus M. Kelley.

Glaeser, Edward L. and Andrei Shleifer. 2003. "The Rise of the Regulatory State," Journal of Economic Literature 41 (June): 401-425.

Goodrich, Carter. 1960. Government Promotion of American Canals and Railroads, 1800-1890. New York: Columbia University Press.

Goodrich, Carter, et al. 1961. Canals and American Economic Development. New York: Columbia University Press.

Gray, Ralph D. 1967. The National Waterway: A History of the Chesapeake and Delaware Canal, 1769-1965. Urbana: University of Illinois Press.

Gunn, L. Ray. 1988. The Decline of Authority: Public Economic Policy and Political Development in New York State, 1800-1860. Ithaca: Cornell University Press.

Hammond, Jabez D. 1846. The History of Political Parties in the State of New York 2 vols. $4^{\text {th }}$ edition. Cooperstown: H\&E Phinney.

Hanyan, Craig and Mary Hanyan. 1996. DeWitt Clinton and the Rise of the People's Men. Montreal: McGill-Queens.

Hartz, Louis. 1948. Economic Policy and Democratic Thought: Pennsylvania 1776-1860. Cambridge, MA: Harvard University Press.

Hasse, Adelaide. 1907. Index of Economic Material in Documents of the States of the United States: New York, 1789-1904. Washington: Carnegie Institution.

Hellman, Joel S., and Geraint Jones and Daniel Kaufmann. 2000. "Seize the State, Seize the Day: State Capture, Corruption, and Influence in Transition." World Bank Policy Working Paper 2444. Washington, D.C.: The World Bank.

Hunt's Merchants' Magazine and Commercial Review. 1850. "Internal Improvements in the State of New York.” 28: (September 1850): 259-269; (October 1850): 383-395; and (November 1850): 497-508.

King, Charles. 1843. A Memoir of the Construction, Cost, and Capacity of the Croton Aqueduct. New York: Charles King.

La Porta, Rafael, Florencia Lopez-de-Silanes, Andrei Shleifer, and Robert Vishny. 1999. "The Quality of Government," Journal of Law Economics and Organization 15 (March): 222-229. 
Larson, John Lauritz. 2001. Internal Improvements: National Public Works and the Promise of Popular Government in the Early United States. Chapel Hill: University of North Carolina Press.

Laws of the State of New York in Relation to the Erie and Champlain Canals, Together with the Annual Reports of the Canal Commissioners and other Documents requisite for a complete official history of these works (2 vols.). 1825. Albany: E. and E. Horsford.

MacGill, Carol S., et al. 1917. History of Transportation in the United States before 1860. Washington: Carnegie Institution.

Magrath, C. Peter. 1966. Yazoo: Law and Politics in the New Republic; The Case of Fletcher vs. Peck. Providence: Brown University Press.

Majewski, John. 2000. A House Dividing: Economic Development in Pennsylvania and Virginia before the Civil War. Cambridge: Cambridge University Press.

McCullough, David. 1977. The Path between the Seas: The Creation of the Panama Canal, 1870-1914. New York: Simon \& Schuster.

McGrane, Reginald C. 1935. Foreign Bondholders and American State Debts. New York: Macmillan.

Merrow, Edward W. 1988. Understanding the Outcomes of Megaprojects: A Quantitative Analysis of Very Large Civilian Projects. Santa Monica: The RAND Corporation.

Miller, Nathan. 1962. The Enterprise of a Free People: Aspects of Economic Development in New York State During the Canal Period, 1792-1838. Ithaca: Cornell University Press.

Moulton, H.G. 1915. "The Cost of the Erie Barge Canal," Journal of Political Economy 23 (May): 490-500.

Murphy, Kevin M., Andrei Shleifer, and Robert W. Vishny. 1993. "Why is Rent-Seeking so Costly to Growth?," American Economic Review 83 (May): 409-414.

Nettels, Curtis. 1962. The Emergence of a National Economy, 1775-1815. New York: Holt, Rinehart and Winston, 1962.

New York Times. 1871. How New York is Governed: Frauds of the Tammany Democrats. New York: New York Daily Times.

North, Douglass C. 1991. Structure and Change in Economic History. New York: Norton.

Pierce, Harry H. 1953. Railroads of New York: A Study of Government Aid, 1826-1875. 
Cambridge, MA: Harvard University Press.

Quirk, James and Rodney D. Fort. 1992. Pay Dirt: The Business of Professional Team Sports. Princeton: Princeton University Press.

University Press.

1999. Hard Ball: The Abuse of Power in Pro Team Sports. Princeton: Princeton

Ransom, Roger. 1964. "Canals and Development: A Discussion of the Issues." American Economic Review 54 (May): 365-376.

Renwick, James. 1842. Life of Dewitt Clinton. New York: Harper \& Brothers. Report of the Commissioners of the State of New York on the Canals from Lake Erie to the Hudson River and from Lake Champlain to the same. Presented to the Legislature, January $31^{\text {st }}, 1818$. 1818. Albany: J. Buel.

Report of the Select Committee of the Assembly of 1846, upon the Investigation of Frauds in the Expenditure of the Public Monies upon the Canals of the State of New York. (February 17, 1847) (No.100). 1847. Documents of the Assembly of the State of New York, Seventieth Session. vol. 3. Albany: Charles van Benthuysen.

Report of Select Committee on Reports etc., Relative to Canal Frauds. 1851. Testimony and Exhibits taken by committee approved by the Assembly of 1850 to investigate certain alleged canal frauds April 17, 1851 and July 10, 1851 (No. 158 and 156). Documents of the Assembly of the State of New York, Seventy-fourth Session, 1851. vol. 6. Albany: Charles van Benthuysen.

Report of the Committee Appointed by the Senate to Investigate and Inquire into the Management of the Canals of this State the Official Conduct of Any Person Now, or Heretofore, Officially Connected Therewith, and also the Official Conduct of Persons Comprising the Canal Contracting Board. 1868. (January 22, 1868) (No. 32) Documents of the Assembly of the State of New York Ninety-first Session, 1868.vol. 4. Albany: Charles van Benthuysen.

Report of Joint Committee of Senate and Assembly in Relation to Canal Fraud, Investigation. 1875. (May 5, 1875) (No. 152) Documents of the Assembly of the State of New York, NinetyEighth Session, 1875. vol. 10. Albany: Weed, Parsons and Company.

Report of the Joint Committee of the Senate and Assembly, Relative to Canal Investigation. 1876. (March 3, 1876) (No. 78). Documents of the Senate of the State of New York, Ninetyfifth Session. vol. 6. Albany: Jerome B. Parmenter.

Rose-Ackerman, Susan. 1999. Corruption and Government: Causes, Consequences, and Reform. Cambridge: Cambridge University Press. 
Rosenberg, Nathan and L.E. Birdzell, Jr. 1986. How the West Grew Rich: The Economic Transformation of the Industrial World. New York: Basic Books.

Scheiber, Harry N. 1969. Ohio Canal Era: A Case Study of Government and the Economy, 1820-1861. Athens: Ohio University Press.

Seavoy, Ronald E. 1982. The Origins of the American Business Corporation, 1784-1855:

Broadening the Concept of Public Service During Industrialization. Westport: Greenwood Press.

Shaw, Ronald E. 1966. Erie Water West: A History of the Erie Canal, 1792-1854. Lexington: University of Kentucky Press.

1990. Canals for a Nation: The Canal Era in the United States, 1790-1860. Lexington: University Press of Kentucky.

Sheriff, Carol. 1996. The Artificial River: The Erie Canal and the Paradox of Progress, 18171862. New York: Hill and Wang.

Shleifer, Andrei and Robert W. Vishny. 1993. "Corruption," Quarterly Journal of Economics 108 (August): 599-617.

Sowers, Don C. 1914. The Financial History of New York State from 1789 to 1912. New York: Columbia University.

Stevens, Joseph E. 1988. Hoover Dam: An American Adventure. Norman: University of Oklahoma Press.

Sullivan, Neil J. 2003. The Diamond in the Bronx: Yankee Stadium and the Politics of New York. New York: Oxford University Press, 2003.

Tocqueville, Alexis de. 1961(orig. publ. 1835). Democracy in America (2 vols.) New York: Schocken Books. .

Toohey, Kristine and A.J. Veal. 2000. The Olympic Games: A Social Science Perspective. Walingford: CABI Publishing.

Wachs, Martin. 1989. "When Planners Lie With Numbers," Journal of the American Planning Association. 55 (4): 476-479.

Walker, Barbara K. and Warren S. 1963. The Erie Canal: Gateway to Empire: Selected Source Materials for College Research Papers. Boston: D.C. Heath.

Weingroff, Richard F. 1996. "Federal- Aid Highway Act of 1956: Creating the Interstate System". Public Roads 60 (Summer): 10-17. 
Whitford, Noble E. 1906. History of the Canal System of the State of New York together with Brief Histories of the Canals of the United States and Canada.2 vols. Albany: Brandon Printing Company. 
Table 1

Actual Expenditures to Projected Costs on Major Public Works: 1817 to 2004

\begin{tabular}{|c|c|c|c|c|}
\hline Years & Public Works & $\begin{array}{l}\text { Projected } \\
\text { Cost } \\
\text { (current US\$ } \\
\text { millions) }\end{array}$ & $\begin{array}{l}\text { Actual } \\
\text { Expenditures } \\
\text { (current US\$ } \\
\text { millions) }\end{array}$ & $\begin{array}{l}\text { Ratio of Actual to } \\
\text { to Projected Cost }\end{array}$ \\
\hline $1817-1825$ & $\begin{array}{l}\text { Erie Canal } \\
\text { (New York State) }\end{array}$ & $\$ 5.75$ & $\$ 8.40$ & 1.46 \\
\hline $1824-1829$ & $\begin{array}{l}\text { Chesapeake and } \\
\text { Delaware Canal } \\
\text { (US Government) }\end{array}$ & 1.35 & 2.20 & 1.63 \\
\hline $1825-1835$ & $\begin{array}{l}\text { Ohio and Miami } \\
\text { Canals (Ohio) }\end{array}$ & 5.13 & 5.93 & 1.16 \\
\hline $1835-1862$ & $\begin{array}{l}\text { Enlargement and } \\
\text { Improvement of Erie } \\
\text { Canal (NY State) }\end{array}$ & 12.42 & 30.00 & 2.42 \\
\hline $1838-1843$ & $\begin{array}{l}\text { Croton Aqueduct } \\
\text { (City and County } \\
\text { of New York) }\end{array}$ & 8.46 & 11.45 & 1.35 \\
\hline 1883-1926 & $\begin{array}{l}\text { Mississippi River } \\
\text { Levee Line } \\
\text { (US Government) }\end{array}$ & 11.45 & $>229.00$ & $>20.00$ \\
\hline $1902-1913$ & $\begin{array}{l}\text { Panama Canal } \\
\text { (US Government) }\end{array}$ & 145.00 & 298.00 & 2.06 \\
\hline 1931-1936 & $\begin{array}{l}\text { Hoover Dam } \\
\text { (U.S. Government) }\end{array}$ & 48.89 & 54.70 & 1.12 \\
\hline $1952-1953$ & $\begin{array}{l}\text { Interstate Highways } \\
\text { (US \& State Government }\end{array}$ & 25.00 & 477.50 & 19.10 \\
\hline 1966-1975 & $\begin{array}{l}\text { Louisiana Superdome } \\
\text { (Louisiana) }\end{array}$ & 35.00 & 163.00 & 4.66 \\
\hline 1971-1975 & $\begin{array}{l}\text { Renovation of } \\
\text { Yankee Stadium } \\
\text { (New York City) }\end{array}$ & 24.00 & 100.00 & 4.17 \\
\hline 1991-2004 & $\begin{array}{l}\text { Boston Central Artery/ } \\
\text { Tunnel or "Big Dig" } \\
\text { (US Government) }\end{array}$ & 2800.00 & $>14600.00$ & $>5.21$ \\
\hline
\end{tabular}


Notes and Sources: Our projected cost figures generally pertain to the estimated construction costs at the time the projects were approved. The periods specified for the projects begin with the year of approval (or cost estimate), and end with the completion of the project. We have for each project specified the government that was the initiator of the project, or the major funding source. The cost figures for the Erie Canal include the cost of the Champlain Canal. The projected costs were prepared in March 1817, and were those in place when the legislature approved the plan in that year. For those estimates and the actual cost of constructing the two canals, see Hunt's Merchants' Magazine (1850, 386). For the Chesapeake and Delaware Canal, see Gray $(1967,51)$; the cost estimate we use here is the one prepared by the consulting engineers, which leads to a slightly lower ratio of expenditures to estimated costs. For the Ohio and Miami Canals, see Bogart (1924, 28-29 and 76). For the estimates for the Croton Aqueduct, see King (1843, 176 and 221). For the estimates of projected (prepared by the Mississippi River Commission in 1883) and actual expenditures on building the levee line to control flooding on the Mississippi River, see Frank (1930) and the House Committee on Flood Control (1927-28). This project was not completed by 1927. For the projected costs of constructing the Panama Canal (presented in 1901 by a commission appointed by President McKinley, and voted on by Congress in 1902), see Bishop (1913, 428-29). For a more optimistic estimate, see McCulloch (1977, 610-11). For a more pessimistic estimate, see Moulton (1915). Our cost figures do not include the $\$ 40$ million that was paid to obtain the land, property, and rights of an unsuccessful French effort to build the canal. For discussion of the estimated cost of the Hoover Dam (taken as the winning bid by the contractor), and the ultimate cost of the construction to the government, see Stevens $(1988,252)$. For the figures on the Louisiana Superdome, see Danielson $(1997,279)$. Also see Quirk and Fort $(1992,158)$. The figures for Interstate Highways pertain to the Federal-Aid Highway Act of 1952, and come from Weingroff $(1996,4)$. For an extended discussion of the background and development of the New York City project to renovate Yankee Stadium, as well as of how the cost of the project were underestimated, see Sullivan (2001, chap. 7). For the estimated costs of the "Big Dig" (a highway/bridge/tunnel project in Boston and the "single largest civil-engineering project in American history"), see The Economist (2004, 28). 
MAP OF NEW YORK CANALS AND RAILROADS, c. 1858

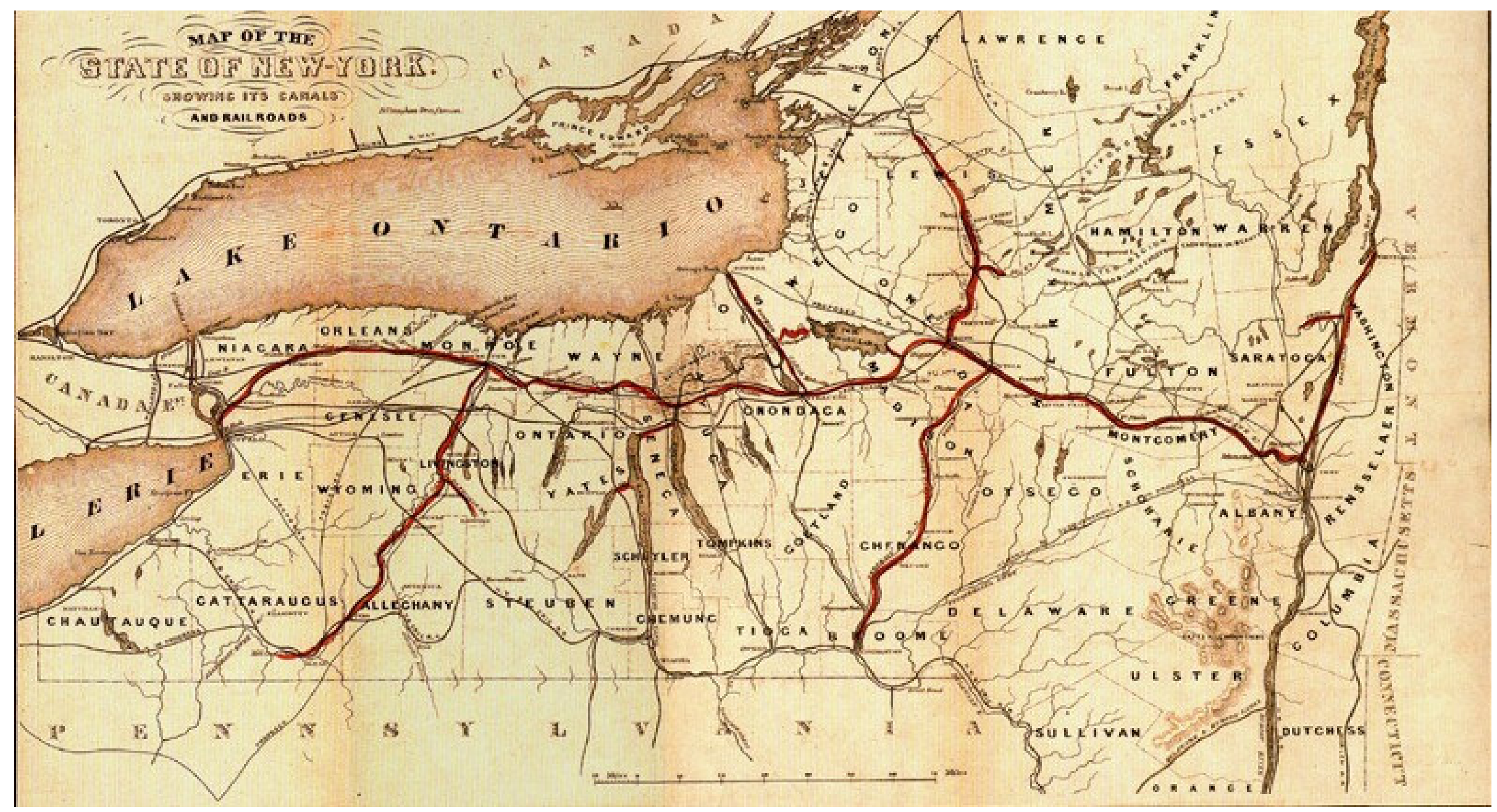

